\title{
Prolonged Hypercarbia in the Awake Newborn Piglet: Effect on Brain Blood Flow and Cardiac Output
}

\author{
ANN-MARI BRUBAKK, WILLIAM OH, AND BARBARA S. STONESTREET \\ Department of Pediatrics, Women and Infants Hospital of Rhode Island and Brown University Program in \\ Medicine, Providence, Rhode Island 02908
}

\begin{abstract}
In adults, exposure to prolonged hypercarbia results in a normalization of the extravascular brain $\mathrm{pH}$ associated with a reduction in brain blood flow (BBF). Following prolonged hypercarbia, sudden normalization of the arterial $\mathrm{PCO}_{2}$ also produces a change in the extravascular brain $\mathrm{pH}$ to an alkaline state, resulting in a marked decrease in BBF. We examined these physiologic phenomena in newborn subjects by exposing seven awake, spontaneously breathing newborn piglets to $4 \mathrm{~h}$ of sustained hypercarbia $\left(\mathrm{PaCO}_{2}:\right.$ 60-70 $\mathrm{mm} \mathrm{Hg}$ ) followed by a 45-min normocarbic period. Total and regional BBF, cardiac output (radionuclide-labeled microsphere method), arterial blood pressure, plasma catecholamine and lactate concentrations, blood gases, oxygen contents, and hematocrits were measured during a baseline period, at $1 / 2,2$, and $4 \mathrm{~h}$ of sustained hypercarbia and $1 / 4$ and $3 / 4 \mathrm{~h}$ following an abrupt onset of normocarbia. The initial 2.5 -fold increase in total BBF during hypercarbia persisted for $2 \mathrm{~h}$ and at 4 $h$ decreased significantly below the level of the $30-\mathrm{min}$ hypercarbic measurement, although the values still remained 2-fold above the baseline values. Brain tissue pH was reduced at the onset of hypercarbia, remaining unchanged throughout the hypercarbic period. Both total $\mathrm{BBF}$ and brain tissue $\mathrm{pH}$ returned to baseline values following the return to normocarbia. Changes in regional BBF were similar to that of total BBF with the exception of the boundary zone (periventricular area in the frontoparietal region of the cerebrum, adjacent to the caudate nucleus) and the parietal area (site of the brain tissue $\mathrm{pH}$ electrode), where a significant decrease from the peak hyperemia was not observed. Choroid plexus blood flow demonstrated a small initial increase over normocarbic baseline values. Plasma bicarbonate concentrations did not change during the studies. Following the onset of hypercarbia, heart rate and cardiac output increased significantly whereas plasma lactate concentrations decreased significantly. There was also an increase in the percentage of cardiac output distributed to the brain. The increase in cardiac output persisted throughout the hypercarbic period and returned to baseline levels during normocarbia. Mean arterial blood pressure increased significantly at the 4-h hypercarbic period and this increase persisted during normocarbia. We conclude that in newborn piglets 1) hypercarbia resulted in cerebral hyperperfusion, accompanied by marked fall in brain tissue
\end{abstract}

Received January 27, 1986; accepted August 11, 1986.

Address for correspondence and reprints: Barbara S. Stonestreet, M.D., Women and Infants Hospital of Rhode Island, 50 Maude Street, Providence, RI 02908.

Supported by the National Research Training Grant IT 32-HD-07232, National Institute of Child Health and Human Development Bethesda, MD and a grant-inaid from the American Heart Association with funds contributed in part by the Rhode Island Affiliate. A.M.B. was supported by Leiden University, Leiden, The Netherlands.
$\mathrm{pH}, 2$ ) prolongation of hypercarbia for $4 \mathrm{~h}$ was associated with a slight but significant reduction in the cerebral hyperperfusion independent of changes in brain tissue $\mathrm{pH}$, and 3 ) in contrast to that observed in adult subjects, the abrupt normalization of arterial $\mathrm{PCO}_{2}$ was not associated with a fall of BBF below the prehypercarbic values. ( $\mathrm{Pe}$ diatr Res 21: 29-33, 1987)

\section{Abbreviations}

BBF, brain blood flow

IVH, intraventricular hemorrhage

MABP, mean arterial blood pressure

Hypercarbia results in cerebral vasodilation and increased BBF in fetal and newborn animals (1-3) and may be an important factor in the development of IVH in premature infants (4). In infants with respiratory disorders, $\mathrm{PaCO}_{2}$ may exceed the physiologic range for considerable amounts of time despite appropriate ventilatory therapy.

In adult animals and humans, acid-base adjustments normalize the brain tissue $\mathrm{pH}$ during prolonged hypercarbia, resulting in a diminution of cerebral vasodilation (5-7). Because the blood brain barrier is readily permeable to carbon dioxide and relatively impermeable to bicarbonate ion, acute normalization of systemic $\mathrm{PaCO}_{2}$ and $\mathrm{pH}$ in chronically hypercapnic adult humans and dogs results in an alkalinization of extravascular brain $\mathrm{pH}$ and markedly reduces $\mathrm{BBF}(6,7)$. Whether this phenomenon also exists in newborns is not known and may if present contribute to the development of central nervous system abnormalities in the neonatal period.

We hypothesized that $4 \mathrm{~h}$ of hypercarbia in newborns may result in a normalization of extravascular brain $\mathrm{pH}$ and $\mathrm{BBF}$, and an acute normalization of $\mathrm{PaCO}_{2}$ following this 4-h period of hypercarbia may result in a reduction of BBF below prehypercarbic levels.

\section{MATERIALS AND METHODS}

Seven 2- to 4-day-old newborn piglets with a mean weight of $1.21 \mathrm{~kg}$ (range 1.05-1.43) were obtained from a local farmer. The piglets remained with the sows until the morning of the study. Catheter placement was performed on an infant radiant warmer under general anesthesia using a mixture of $70 \%$ nitrous oxide and $30 \%$ oxygen administered via a head hood and local anesthesia with $1 \%$ lidocaine. A Sentinel line catheter (ID 0.67 $\mathrm{mm}$, OD $1.05 \mathrm{~mm}$, Argyle, St. Louis, MO) was introduced into the left ventricle via the right brachial artery for injection of radionuclide-labeled microspheres. Polyvinyl catheters (ID 0.58 
mm, OD $0.9 \mathrm{~mm}$, Bolab Inc. Lake Havasu, AZ) were placed in: 1) the left brachial artery for withdrawal reference blood samples, 2) the abdominal aorta via the femoral artery for determination of blood pressure, heart rate, arterial blood gases, hematocrit, and plasma catecholamine and lactate concentrations, and 3) the inferior vena cava via the femoral vein for continuous infusion of $5 \%$ glucose and replacement of blood during the study. All incisions were infiltrated with a $2 \%$ oxylocaine gel before closure of the skin to insure prolonged analgesia.

The animals were then removed from the head hood, restrained in a prone position, and ventilated via a veterinary mask connected to an Isolette Amsterdam type infant ventilator (Narco, Warminster, PA) with $70 \%$ nitrous oxide and $30 \%$ oxygen. Following local anesthesia and incision of the periosteum, a small burr hole (approximately $5 \mathrm{~mm}$ in diameter) was made in the left parietal region of the skull with a hand held drill. A rubber stopper with a similar diameter was then secured with sutures over the burr hole between the bone and skin. The dura was then pierced with a stylette, care was taken to avoid blood vessels, and a Roche glass $\mathrm{pH}$ tissue electrode (Roche Laboratories Electronics Inc., Cranbury, NJ) was inserted approximately $4 \mathrm{~mm}$ into the brain tissue via the rubber stopper. The electrode was then secured to the rubber stopper with plaster of Paris and this cast fixed to the scalp with surgical steel sutures.

Following surgery the animals were allowed to recover in a padded enclosed box where they remained for the duration of the study, therefore the awake unrestrained newborn piglets were studied with a minimum of external stimulae. The tissue $\mathrm{pH}$ electrode cord and catheters were exteriorized via small openings in the box. Microspheres $(15 \pm 5 \mu \mathrm{m}$, New England Nuclear, Boston, MA) labeled with ${ }^{51} \mathrm{Cr},{ }^{46} \mathrm{Sc},{ }^{95} \mathrm{Nb},{ }^{113} \mathrm{Sn},{ }^{103} \mathrm{Ru}$, and ${ }^{57} \mathrm{Co}$ were utilized to measure brain blood flow and cardiac output according to the method of Heymann et al. (8). For each blood flow measurement, approximately $9 \times 10^{5}$ radionuclide-labelled microspheres suspended in $10 \%$ dextran and $0.01 \%$ Tween were injected over $30 \mathrm{~s}$ into the left ventricle. The reference blood sample from the axillary artery was collected continuously for 2 min beginning $15 \mathrm{~s}$ prior to the microsphere injection at a withdrawal rate $1.03 \mathrm{ml} / \mathrm{min}$ using a constant withdrawal pump (Harvard Apparatus, Millis, MA). Blood losses from study sampling were replaced with an equal volume of blood obtained from a young donor piglet. Adequate mixing of microspheres in the left ventricle were confirmed by comparing blood flow to the left and right cerebrum $(r=0.98, p<0.001, n=7)$.

Following baseline blood flow determinations, a gas mixture containing $15 \% \mathrm{CO}_{2}, 20 \% \mathrm{O}_{2}$ with balance nitrogen was introduced into the enclosed vented box in order to obtain a $\mathrm{PaCO}_{2}$ between 60 and $70 \mathrm{~mm} \mathrm{Hg}$. This level of hypercarbia was maintained for $4 \mathrm{~h}$. The gas mixture was humidified and heated to $28^{\circ} \mathrm{C}$ in order to prevent alterations in the piglets body temperature. Blood flow was measured $1 / 2,2$, and $4 \mathrm{~h}$ following the onset of hypercarbia. Immediately following the third hypercarbia measurement, after $4 \mathrm{~h}$ of carbon dioxide exposure, the gas mixture was withdrawn and compressed air was substituted. The box containing the piglet was then flushed with 8 liter $/ \mathrm{min}$ of compressed air in order to immediately reduce the ambient carbon dioxide concentration. Following this initial reduction of ambient carbon dioxide from the box containing the piglet, compressed air was delivered at 2 liter/min for the remainder of the study and repeat measurements as indicated above were obtained $1 / 4$ and $3 / 4 \mathrm{~h}$ after the return to normocarbia.

MABP was continuously monitored during the study using a Hewlett Packard $1280 \mathrm{~B}$ pressure transducer and recorded on a Hewlett Packard 7754 A polygraph (Lexington, MA). MABP and heart rate represented the mean of five determinations during each blood flow measurement. Lactic acid concentration was determined according to the method of Marbach and Weil (9). Plasma epinephrine and norepinephrine concentrations were obtained by collecting $2 \mathrm{ml}$ of arterial blood in a chilled heparinized tube containing reduced glutathione. The blood was centrifuged at $0^{\circ} \mathrm{C}$ and the plasma stored at $-70^{\circ} \mathrm{C}$ until the time of the assay. Determinations of plasma catecholamine concentrations were performed by liquid chromatography using the electrochemical detection method of Hjemdahl et al. (10). The coefficient of the variation for norephinephrine with this method was $9.5 \%$ and for epinephrine $9.4 \%$. The lower limit of sensitivity was approximately $20 \mathrm{pg}$ for injected norepinephrine and $30 \mathrm{pg}$ for injected epinephrine. Recovery of catecholamine from plasma was between 70-80\%. Following each blood flow determination $\mathrm{PaCO}_{2}, \mathrm{PaO}_{2}, \mathrm{pH}$, and bicarbonate were measured using a corning 175 Corning Blood Gas Analyzer (Medfield, MA). Oxygen contents were measured with a Lex- $\mathrm{O}_{2}$-Con (Lexington Instruments, Waltham, MA). Arterial hematocrit was measured using the microhematocrit method.

The brain $\mathrm{pH}$ electrode was calibrated with two test solutions with a pH of 7.0 and 7.4, respectively, prior to placement into the brain tissue. Brain tissue $\mathrm{pH}$ was monitored continuously on a recorder. The calibration was verified following each study. Because of technical difficulties with the $\mathrm{pH}$ electrode placement, brain tissue $\mathrm{pH}$ was measured in five of the seven study animals. Figure 1 illustrates a representative brain tissue $\mathrm{pH}$ recording during the study.

At the end of the study the animals were sacrificed with an overdose of sodium thiamylal, the catheter placement was confirmed by autopsy, the $\mathrm{pH}$ electrode removed, and the brain removed and weighed prior to and following fixation with $10 \%$ formaldehyde.

For determination of regional BBF, the brain was divided into the following sections: cerebrum, brain stem (from the superior colliculus to the spinal cord), cerebellum, thalamus, caudate nuclei (floor of the lateral ventricles), the boundary zone (periventricular area in the frontoparietal region of the cerebrum, adjacent to the caudate nucleus), and the choroid plexus. In order to determine if the insertion of the $\mathrm{pH}$ electrode into the brain tissue altered local brain blood flow, the electrode site in the parasagittal left side of the cerebrum and the corresponding right side were also isolated. After removal of the brain, the remaining organs and the carcass were weighed and incinerated for $96 \mathrm{~h}$ for cardiac output determination as previously described $(1,8)$.

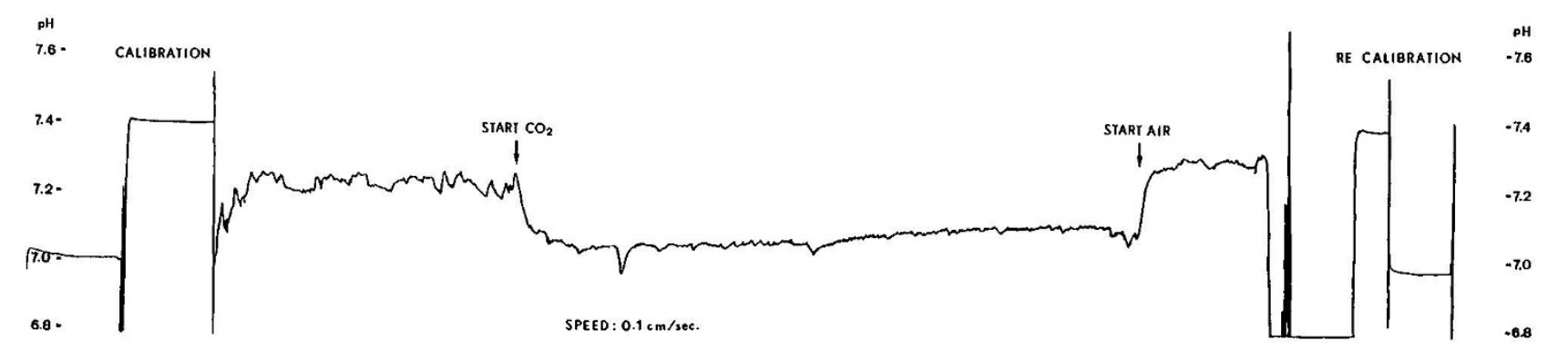

Fig. 1. A representative brain tissue $\mathrm{pH}$ recording during the study. 
Changes from baseline during prolonged hypercarbia followed by normocarbia and changes during prolonged hypercarbia were examined by analysis of variance for repeated measurements. If a significant difference was found $(p<0.05)$, the Dunnett's multiple range $t$ test was used to compare the means to the baseline values, during prolonged hypercarbia the 2 - and 4-h determinations were compared to the 30 -min measurement. Analysis of variance with the multiple comparison NewmanKeuls post hoc test was also used to detect significant differences in blood flow among the brain regions during the baseline, the three hypercarbic, and two normocarbic measurements. All values are expressed as mean \pm SEM.

\section{RESULTS}

Table 1 summarizes the blood gas, hematocrit, oxygen content, and bicarbonate and plasma lactic acid values during the studies. The rise in $\mathrm{PaCO}_{2}$ obtained at $30 \mathrm{~min}$ of hypercarbia remained unchanged during the ensuing $4 \mathrm{~h}$. Following the termination of hypercarbia, $\mathrm{PaCO}_{2}$ returned to normocarbic levels for newborn piglets, however, during the first of the two normocarbic measurements $\mathrm{PaCO}_{2}$ was still slightly, but significantly elevated, compared with the baseline values. The respiratory acidosis was associated with a significant decrease in the base excess. The $\mathrm{PaO}_{2}$ and hematocrit values did not change. Oxygen content decreased slightly but significantly at $30 \mathrm{~min}$ of hypercarbia, the remainder of the values were similar to baseline. There were no significant changes in the plasma bicarbonate values. A significant decrease in lactic acid concentration occurred during the third hypercarbic measurement period.

As shown in Figure 2, total BBF increased approximately 2.5 times the baseline value during the induction of hypercarbia and remained elevated during the first $2 \mathrm{~h}$ of hypercarbia. At $4 \mathrm{~h}$ of hypercarbia, total $\mathrm{BBF}$ was reduced significantly compared to the 30-min hypercarbic determination. Reduction of the $\mathrm{PaCO}_{2}$ to the normocarbic range resulted in a reduction of $\mathrm{BBF}$ to baseline levels. As expected, the brain tissue $\mathrm{pH}$ was significantly decreased at $30 \mathrm{~min}$ of hypercarbia. During the remainder of the hypercarbic period, brain tissue $\mathrm{pH}$ increased slightly, however, significant changes were not observed. A return to baseline levels was observed during the normocarbic period.

Blood flow to all regions of the brain increased significantly during the first 30 min of hypercarbia (Table 2). Blood flow to the brain stem and thalamus was significantly greater than to the cerebrum during the $30-\mathrm{min}$ hypercarbic period. Compared to the peak hyperemic value at 30 -min of hypercarbia, significant reductions in regional blood flow were observed in the cerebrum, cerebellum, brain stem, thalamus, and caudate nucleus following $4 \mathrm{~h}$ of hypercarbia. The blood flow to the boundary zone and parietal area also declined when compared with the 30-min hypercarbia period, but these changes were not statistically sig- nificant. Choroid plexus blood flow was higher than blood flow to the cerebrum and increased significantly during the first 30 min of hypercarbia and remained elevated during the hypercarbic periods. There were no significant differences from the baseline blood flow values to any brain region examined following the return to normocarbia.

Table 3 summarizes the changes in total BBF expressed as percentage of cardiac output, cardiac output, heart rate, plasma catecholamine concentrations, and MABP during the study periods. The percentage of cardiac output distributed to the brain was significantly increased during hypercarbia, decreased significantly at $4 \mathrm{~h}$ of hypercarbia compared with the 30 -min determination and returned to baseline during normocarbia. Cardiac output increased significantly and remained elevated and unchanged throughout the three hypercarbic periods. The return to normocarbia resulted in a decrease in cardiac output. The induction of hypercarbia resulted in a temporary increase in the heart rate and catecholamine concentrations: the heart rate, epinephrine, and norepinephrine levels were significantly elevated during
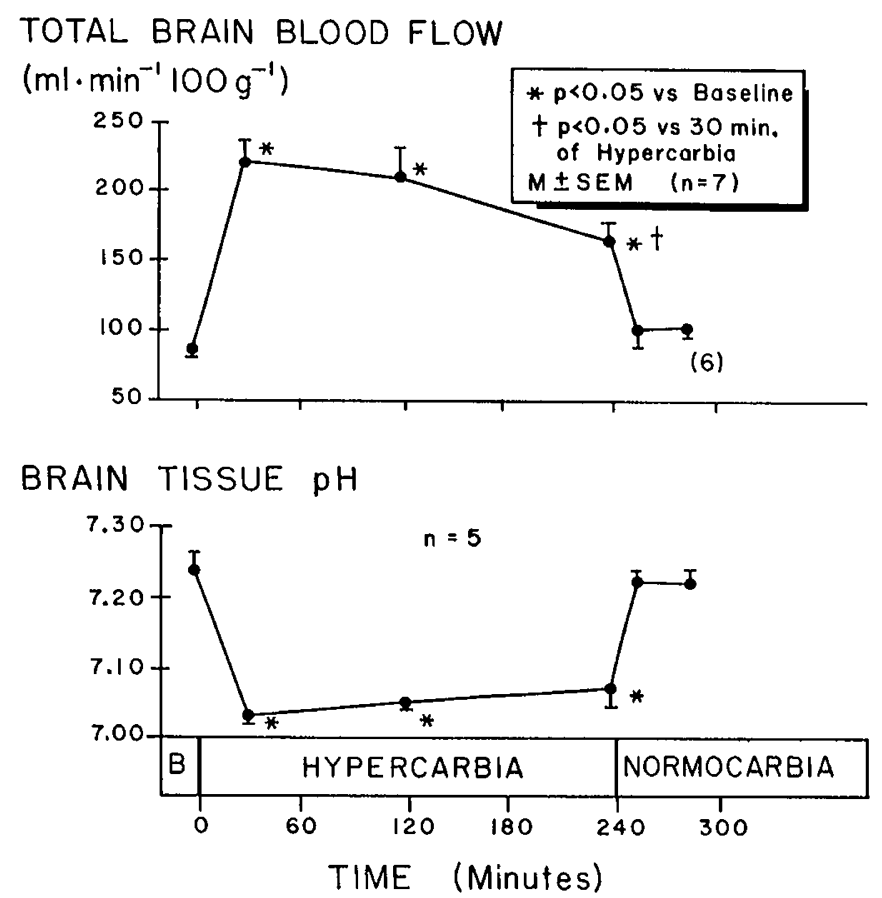

Fig. 2. BBF and brain tissue $\mathrm{pH}$ during baseline and 30,120 , and $240 \mathrm{~min}$ of hypercarbia and 15 and $45 \mathrm{~min}$ following return to normocarbia. $n=7$ except when indicated in parentheses.

Table 1. Blood gases, hematocrit, oxygen content, bicarbonate, and lactic acid values during the six study periods $[$ mean $\pm S E M(n=7)]$

\begin{tabular}{|c|c|c|c|c|c|c|}
\hline \multirow[b]{2}{*}{ Variable } & \multirow{2}{*}{$\begin{array}{c}\text { Baseline } \\
0 \mathrm{~min}\end{array}$} & \multicolumn{3}{|c|}{ Hypercarbia } & \multicolumn{2}{|c|}{ Normocarbia } \\
\hline & & $30 \mathrm{~min}$ & $120 \mathrm{~min}$ & $240 \mathrm{~min}$ & $255 \mathrm{~min}$ & $285 \mathrm{~min}$ \\
\hline $\mathrm{pH}$ & $7.44 \pm 0.01$ & $7.20 \pm 0.01^{*}$ & $7.19 \pm 0.01^{*}$ & $7.22 \pm 0.02 *$ & $7.38 \pm 0.02 *$ & $7.42 \pm 0.01$ \\
\hline $\mathrm{PaCO}_{2}(\mathrm{~mm} \mathrm{Hg})$ & $39.6 \pm 1.8$ & $66.4 \pm 2.0^{*}$ & $67.9 \pm 1.5^{*}$ & $67.4 \pm 1.7^{*}$ & $44.9 \pm 0.3^{*}$ & $42.6 \pm 1.3$ \\
\hline $\mathrm{BE}(\mathrm{mEg} / \mathrm{liter})$ & $4.1 \pm 1.0$ & $-1.5 \pm 1.8^{*}$ & $-1.6 \pm 1.7^{*}$ & $-0.3 \pm 1.5^{*}$ & $2.8 \pm 1.6^{*}$ & $4.1 \pm 1.4$ \\
\hline $\mathrm{PaO}_{2}(\mathrm{~mm} \mathrm{Hg})$ & $87.3 \pm 3.8$ & $97.7 \pm 8.5$ & $97.1 \pm 9.0$ & $95.1 \pm 12.8$ & $78.9 \pm 4.8$ & $79.0 \pm 5.1$ \\
\hline Hematocrit (\%) & $26 \pm 2$ & $25 \pm 2$ & $26 \pm 2$ & $26 \pm 2$ & $26 \pm 2$ & $26 \pm 2$ \\
\hline $\mathrm{O}_{2}$ content $(\mathrm{ml} / \mathrm{dl})$ & $9.1 \pm 0.7$ & $8.4 \pm 0.7^{*}$ & $8.6 \pm 0.5$ & $8.6 \pm 0.7$ & $8.6 \pm 0.6$ & $9.2 \pm 0.6$ \\
\hline $\mathrm{HCO}_{3}^{-}(\mathrm{mEq} /$ liter $)$ & $26.4 \pm 0.9$ & $25.8 \pm 1.2$ & $25.5 \pm 0.7$ & $26.5 \pm 1.2$ & $26.5 \pm 1.2$ & $27.0 \pm 1.3$ \\
\hline Lactic acid (nM/liter) & $2.99 \pm 0.57$ & $2.75 \pm 0.54$ & $2.03 \pm 0.38$ & $2.06 \pm 0.46 \dagger$ & $3.45 \pm 0.66$ & $3.05 \pm 0.74$ \\
\hline
\end{tabular}

$* p<0.05$ versus baseline.

$\dagger p<0.05$ versus 30 min of hypercarbia. 
Table 2. Regional BBF during the six study periods (mean \pm SEM)*

\begin{tabular}{|c|c|c|c|c|c|c|c|}
\hline \multirow[b]{2}{*}{ Region } & \multirow[b]{2}{*}{ Baseline 0} & \multicolumn{3}{|c|}{ Hypercarbia } & \multicolumn{3}{|c|}{ Normocarbia } \\
\hline & & 30 & 120 & 240 & 255 & 285 & \\
\hline Q̀ cerebrum & $80 \pm 6$ & $182 \pm 19 \dagger$ & $179 \pm 23 \dagger$ & $145 \pm 11+\ddagger$ & $97 \pm 10$ & $96 \pm 7$ & (6) \\
\hline Q brainstem & $86 \pm 5$ & $304 \pm 31+\S$ & $267 \pm 33 \dagger$ & $197 \pm 18+\div$ & $92 \pm 9$ & $97 \pm 8$ & (6) \\
\hline Q thalamus & $98 \pm 6$ & $314 \pm 27+\S$ & $287 \pm 32 \dagger$ & $217 \pm 18+\div$ & $106 \pm 10$ & $113 \pm 9$ & (6) \\
\hline$\dot{Q}$ caudate nucleus & $104 \pm 9$ & $230 \pm 24 \dagger$ & $217 \pm 29 \dagger$ & $184 \pm 19+\div$ & $115 \pm 17$ & $124 \pm 11$ & (6) \\
\hline $\begin{array}{l}\text { Q parietal left (pH elec- } \\
\text { trode site) }\end{array}$ & $94 \pm 7$ & $224 \pm 28 \dagger$ & $239 \pm 38 \dagger$ & $202 \pm 24 \dagger$ & $124 \pm 11$ & $123 \pm 9$ & (6) \\
\hline Q̀ choroid plexus & $389 \pm 70 \S$ & $545 \pm 85+\S$ & $534 \pm 97 \S$ & $534 \pm 82 \S$ & $353 \pm 47 \S$ & $414 \pm 62 \S$ & (6) \\
\hline
\end{tabular}

* $\mathrm{Q}$, blood flow $\left(\mathrm{ml} \cdot \mathrm{min}^{-1} \cdot 100 \mathrm{~g}^{-1}\right)$, number of animals $=7$, except as indicated in parentheses.

$+p<0.05$ versus baseline.

$\ddagger p<0.05$ versus 30 min of hypercarbia.

$\S p<0.05$ versus cerebrum for each time period.

Table 3. Cardiac output, BBF as percentage of cardiac output, plasma catecholamine concentrations, heart rate, and MABP and pulse pressure during the six study periods (mean \pm SEM)*

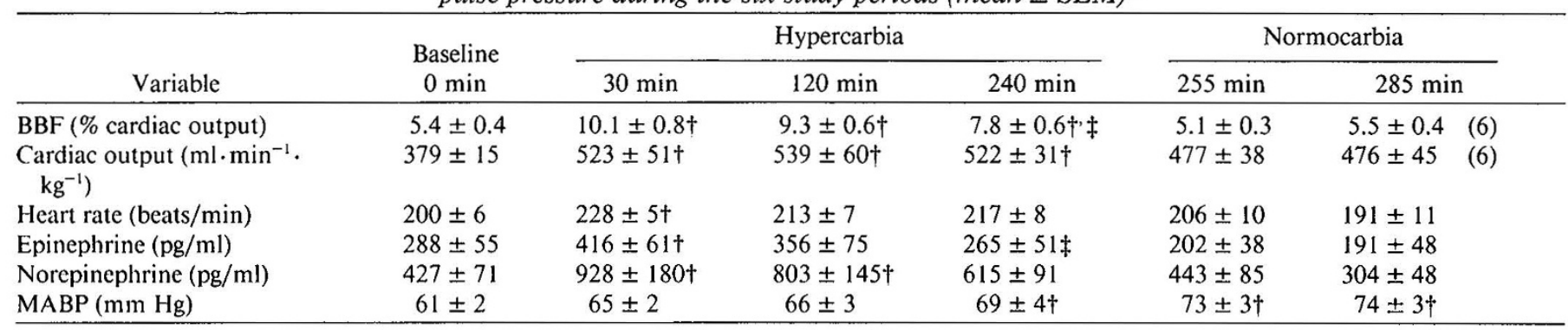

$*$ Number of animals $=7$, except where indicated in parentheses.

$+p<0.05$ versus baseline.

$\ddagger p<0.05$ versus $30 \mathrm{~min}$ of hypercarbia.

the 30-min hypercarbic measurement and the norepinephrine levels remained elevated during the second hypercarbic measurement (120 min). Mean arterial blood pressure increased significantly during the final hypercarbic measurement $(240 \mathrm{~min})$ and remained elevated during normocarbia.

\section{DISCUSSION}

Cerebral vasodilation occurring during hypercarbia is mediated in part through a reduction in the brain extracellular fluid $\mathrm{pH}$ surrounding the blood vessels (11). Following $3 \mathrm{~h}$ of elevated arterial $\mathrm{PCO}_{2}$ values in adult dogs, the intracellular $\mathrm{pH}$ of the brain has been demonstrated to return to normal (6). In addition, because the ependyma offers little resistance to diffusion of ionic charged molecules, the brain extracellular fluid $\mathrm{pH}$ surrounding the blood vessels also returns to normal (12). Moreover, following prolonged periods of hypercarbia, the pial arteriolar vasodilator response to hypercapnia is diminished (5), suggesting that brain blood flow might also be reduced. The major objective of the current study was to determine the effect of $4 \mathrm{~h}$ of hypercarbia on brain tissue $\mathrm{pH}$ and blood flow in newborn subjects. In contrast to that observed in adult dogs (6), our results showed that for yet undetermined reasons, the buffering adjustments within the central nervous system did not result in the anticipated return of the brain tissue $\mathrm{pH}$ to baseline values (Fig. 2) within the time frame examined. Therefore, while there was a slight, however, significant reduction in blood flow to the total brain and some of its regions, hyperperfusion of the central nervous system persisted. In contrast to that observed in the adult dogs (6), it is possible that in the newborn piglet a longer period of hypercarbia, than the $4 \mathrm{~h}$ examined in our study, is required in order to return the brain tissue $\mathrm{pH}$ to normal values, and thereby reduce $\mathrm{BBF}$ to baseline levels. It is also possible that the elevation in brain tissue $\mathrm{pH}$ to normal values was more rapid $(3 \mathrm{~h})$ in the study by Arieff $e t$ al. (6) because the arterial $\mathrm{PCO}_{2}$ was higher $(85 \mathrm{~mm} \mathrm{Hg})$ than in the current study $(67 \mathrm{~mm} \mathrm{Hg})$. The mechanism for the modest reduction in total and regional BBF in our newborn piglets at $4 \mathrm{~h}$ compared with $30 \mathrm{~min}$ of hypercarbia is as yet unexplained.

A critical issue that should be considered in interpreting the data is the validity of brain tissue $\mathrm{pH}$ measurement. One element that may influence its validity is the unavoidable tissue damage during the application of the electrode (14). However, the results we obtained were most likely accurate because each of the five animals demonstrated similar marked changes in brain tissue $\mathrm{pH}$ during the induction of hypercarbia and the return to normocarbia (see Fig. 1 as an example) suggesting that the qualitative changes are consistent within each animal. Our baseline brain tissue $\mathrm{pH}$ values $(7.24 \pm 0.05)$ are somewhat lower than previously reported cerebrospinal fluid values in adult man (15) and higher than intracellular brain $\mathrm{pH}$ values reported in adult dogs using the distribution of ${ }^{14} \mathrm{C}$-labeled dimethadione (6).

During hypercarbia differences in the blood flow among the various regions in the brain are similar to previous findings by us and others in newborn animals $(1,16,17)$. This has been attributed to higher metabolic requirements in the more caudal portions of the brain. During prolonged hypercarbia, BBF in most regions remained elevated suggesting that the buffering shifts in these regions were such that the tissue $\mathrm{pH}$ in these areas remained unchanged. Thus, there were no major alterations in the state of perfusion.

Prolonged hypercarbia was also associated with significant increases in cardiac output and the percentage of cardiac output distributed to the brain. These elevations in cardiac output were 
associated with significant increases in circulating catecholamine concentrations.

Because the blood brain barrier is permeable to carbon dioxide and relatively impermeable to $\mathrm{HCO}_{3}^{-}(18)$, acute normalization of $\mathrm{PaCO}_{2}$ following prolonged hypercarbia may potentially result in an alkaline shift in the extracellular $\mathrm{pH}$ of the brain. In chronically hypercapnic adult humans, this alkaline shift has been shown to result in a very low BBF following a reduction in $\mathrm{PaCO}_{2}$ after a period of prolonged hypercarbia (7). In the newborn piglets, both brain tissue $\mathrm{pH}$ and $\mathrm{BBF}$ returned to baseline values following the normalization of $\mathrm{PaCO}_{2}$. The maintenance of brain tissue $\mathrm{pH}$ at acidotic ranges during hypercarbia indicates a lack of shift in $\mathrm{HCO}_{3}^{-}$in the cerebrospinal and extracellular fluid; therefore the lack of a precipitous fall in BBF due to an "alkaline shift" in tissue $\mathrm{pH}$ when normocarbia followed prolonged hypercarbia is to be expected. However, the increase in mean arterial blood pressure following the return to normocarbia may have influenced the changes in BBF following the termination of hypercarbia. If BBF autoregulation were impaired by $4 \mathrm{~h}$ of hypercarbia, this elevation in blood pressure may have prevented the anticipated reduction in BBF following the return to normocarbia. Alternatively, a longer duration of hypercarbia prior to the return to normocarbia may have resulted in reductions in BBF to values below the baseline levels.

Acknowledgments. The authors acknowledge the excellent technical assistance of Donna Piva.

\section{REFERENCES}

1. Hansen NB. Brubakk AM. Bratlid D. Oh W, Stonestreet BS 1984 The effects of variation in $\mathrm{PaCO}_{2}$ on brain blood flow and cardiac output in the newborn piglet. Pediatr Res 18:1132-1136

2. Ashwal S. Dale PS, Longo LD 1984 Regional cerebral blood flow: studies in the fetal lamb during hypoxia, hypercapnia, acidosis and hypotension. Pediatr Res 18:1309-1316

3. Reivich M, Brann AW, Shapiro H, Rawson J, Sano N 1971 Reactivity of cerebral vessels $\mathrm{CO}_{2}$ in the newborn rhesus monkey. Eur Neurol 6:132-136

4. Hambleton G, Wiggelsworth JHS 1976 Origin of intraventricular hemorrhage in the preterm infant. Arch Dis Child 51:651-659

5. Levasseur JE, Wei EP, Kontos HA, Patterson JL Jr 1979 Responses of pial arterioles after prolonged hypercapnia and hypoxia in the awake rabbit. J Appł Physiol 46:89-95

6. Arieff AI, Kerian A, Massry SG, De Lima J 1976 Intracellular pH of brain: alterations in acute respiratory acidosis and alkalosis. Am J Physiol 230:804812

7. Skinhoj $\mathrm{E} 1968 \mathrm{CBF}$ adaptation in man to chronic hypo- and hypercapnia and its relation to CSF pH. Scand J Clin Lab Invest [Suppl] 102:8A(abstr)

8. Heymann MA, Payne BD, Hoffman JIE, Rudolph MA 1977 Blood flow measurements with radionuclide labelled particles. Prog Cardiovasc Dis 20:55-77

9. Marbach RP, Weil MH 1967 Rapid enzymatic measurement of blood lactate and pyruvate. Clin Chem 13:314-325

10. Hjemdahl P, Daleskog M, Kahan T 1979 Determination of plasma catecholamine by high performance liquid chromatography with electrochemical detection: comparison with an enzymatic method. Life Sci 25:131-138

11. Kontos HA, Raper AJ, Patterson JL 1977 A analysis of vasoactivity of local $\mathrm{pH}, \mathrm{PCO}_{2}$ and bicarbonate on pial vessels. Stroke 8:358-365

12. Haining JL, Turner MD, Pantall RM 1970 Local cerebral blood flow in young and old rats during hypoxia and hypercarbia. Am J Physiol 218:1020-1024

13. Pannier J, Leusen I 1973 Circulation to the brain of the rat during acute and prolonged respiratory changes in the acid base balance. Pflugers Arch 338:347-359

14. Dunn LK, Redstone D, Roe HL, Steer PJ, Beard RW 1978 The relationship between tissue and arterial pH in hypercarbic rabbits. Arch Gynecol 226:3136

15. Huang CT, Lyons HA 1966 The maintenance of acid-base balance between cerebrospinal fluid and arterial blood in patients with chronic respiratory disorders. Clin Sci 31:273-284

16. Rosenberg AA, Jones MD, Traystman RJ, Simmons MA, Molteni RA 1982 Response of cerebral blood flow to changes in $\mathrm{pCO}_{2}$ in fetal newborn and adult sheep. Am J Physiol 242:H862-H866

17. Cavazzuti M, Duffty TE 1982 Regulation of local cerebral blood flow in normal and hypoxic newborn dogs. Ann Neurol 11:247-257

18. Nattie EE, Romer $\mathrm{L} 1978 \mathrm{CSF}^{\mathrm{HCO}} \mathrm{HC}_{3}^{-}$regulation in iso-osmotic conditions: the role of brain $\mathrm{PCO}_{2}$ and plasma $\mathrm{HCO}_{3}^{-}$. Respir Physiol 33:177-198 